\title{
THE ROLE OF SOFT MOBILITY TOWARDS STRENGTHENING URBAN TRANSFORMATION AND SUSTAINABLE WELL-BEING: CASE STUDY: MANSOURA CITY, EGYPT
}

\author{
Mai Wahba Madkour ${ }^{1}$, Alaa A. ELMANZLAWI ${ }^{2}$ \\ ${ }^{1}$ Lecturer, Faculty of Engineering, Tanta University, Egypt \\ ${ }^{2}$ Lecturer, Misr Higher Institute for Engineering and Technology (MET), Egypt \\ Corresponding author: maimadkour@yahoo.com,A.Manzlawy@hotmail.com
}

\begin{abstract}
This research investigates the method of soft mobility role on Egyptian neighborhood unit. It discusses its relationship with the main principles of New Urbanism. And proposes some objectives: Interpret Mobility new concepts in New Urbanism, cite urbanism principles and its trends to conclude soft mobility indicators, design a matrix inventories the compatibility of soft mobility indicators and behavioral dimension. And at last, the matrix tests the combination of indicators and dimensions in an Egyptian traditional urban fabric, at Mansoura City.
\end{abstract}

KEYWORDS: Soft Mobility, New urbanism, sustainable well-being, behavioral dimensions

\section{INTRODUCTION}

In the nineties of the last era, new urbanism \& sustainable urban design and, as a new trend in Urbanism, emerged in synchronization (Duany, 2001). It integrated both functional, perceptual, and behavioral dimensions with environmental sustainable ideas. This paper is to make sense of many ideas and research that bear on urban ecology, sustainable development and mobility effects on them. Mobility is the pillar of the economy and a basic need of the contemporary urban lifestyle. The main question is if our cities can cope with using cars as a sign of mobility, independence, and modernity. The great number of cars on streets, manly solo driving, is jeopardizing the urban context, living, working and relaxing places for people.

The great growth in using cars in traffic with environmental problems also eroded people's possibilities to have free and safe roaming in open spaces. This research is a contribution to debate and discuss mobility patters effects on urban spaces. The idea is developing cities into good streetscapes quality and turn back from nonfunctional, bleak and unattractive urban spaces fairly. Negotiate uses of cars in urban spaces towards changing streetscape to an attractive and multifunctional landscape.

In this reseach, the role of soft mobility in sustainable well-being is explored and discussed against strengthening urban transformation. The main concept of soft mobility is based on the protection and enhancing nature and natural processes, and the benefits gained from nature to serve human needs, are integrated into spatial planning and territorial development, and in strategies of mobility. Soft mobility promotes many solutions and is complementary, to standard solutions.

\subsection{Research problem}

Due to modern architecture, it started changing, the dominance of cars on spatial relationships in city planning professional practice. After the World War II, this trend was named as 
Conventional Suburban Development (CSD) (Duany, 2001). In this research, it was criticized because of the lacking of town centers and pedestrian priority (Urbanism, 1996, pg. 5-10), (Duany, 2001). (CSD) spreads out to large areas of the countryside whatever the population growth rate. It pushes the higher percentage of car ownership in the absence of any public transport system. Today, New Urbanism suggests action plans to (CSD) (Steuteviller, 2009). It starts with some principles of enhancing the communities within walking distances.
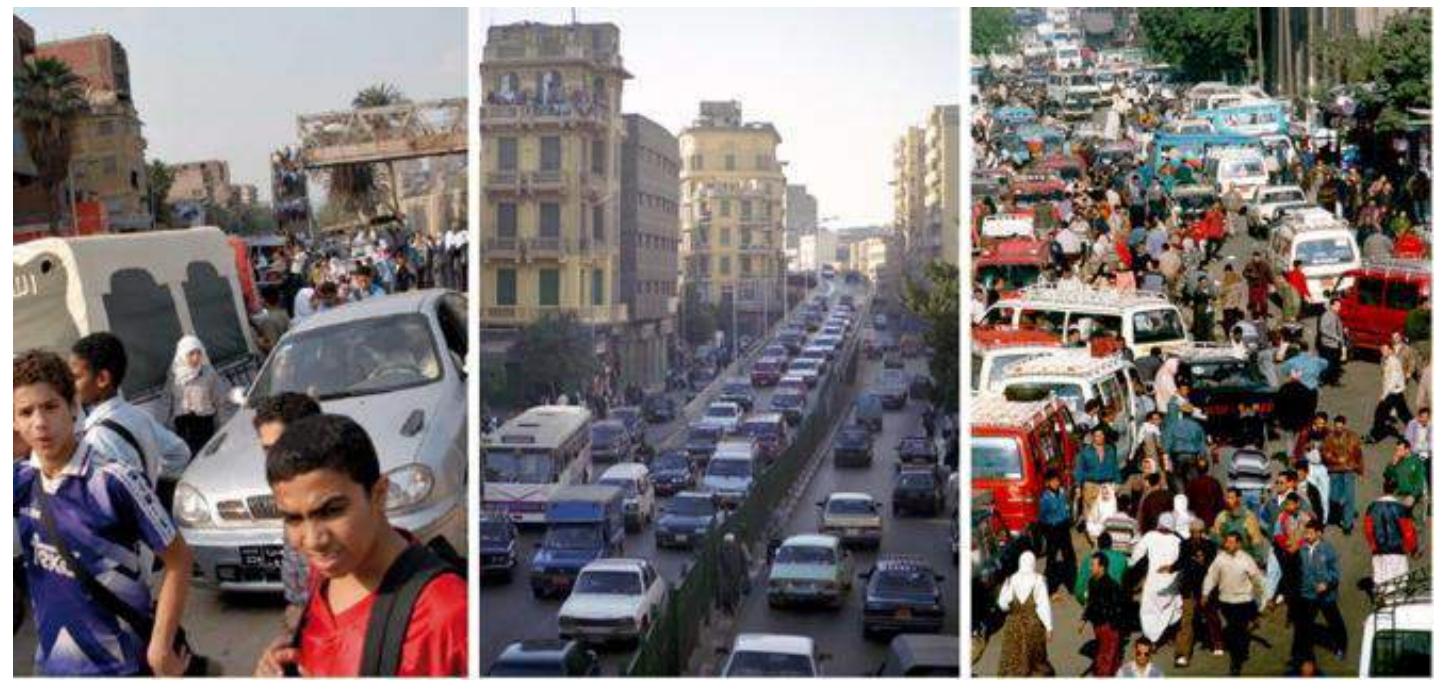

Fig. (1): A Photo showing the Mobility problems in Egypt (Increasing of population densities in urban and rural centers)

Source: Ministry of Housing, Utilities \& Urban communities, 2014 "Urban Future: Egypt's Urban Policies”, PowerPoint presentation.

On the other side, urban mobility, people, and goods transportation, is very essential for economic and social well-being but also is a growing concern. Nowadays urban development faces a great challenge of how to make soft mobility sustainable and environment-friendly and competitiveness (Figure 1). Sustainability has to cope with a steady concern in urban development. So, New Urbanism role is done to improve communities to develop car problems in the forefront of their priorities.

\subsection{Research hypotheses}

Although the Mobility principles of New Urbanism are the most important for many livable cities, therefore, the research suggests a hypothesis addressed as: "if each one of the groups of soft mobility indicators and behavioral dimensions make a livable city, the integration of them will provide convenience solutions to sustainable well-being ."

The paper inventories the indicators of soft mobility inside an Egyptian neighborhood. It provides a matrix addressed as "indicators of soft mobility to " to be tested upon the case study from the behavioral milieu; it is the most tangible to the sustainable wellbeing.

\section{Mobility and Sustainable Wellbeing:}

Mobility is the ability of people and freight to travel where they want to go; it can be measured by kilometers traveled per year: the greater the number, the more the society is mobile. For example, achieving a system for sustainable transport, drivers should drive less; as, driving a car is much more attractive than other transport modes, due to its convenience, independent, flexible, more comfort, fast, safe, and private; cars also provide more pleasure and status than other transport modes. In addition to using soft mobility as a new lifestyle, its main aim is improving 
environmental benefits and urban livability. It includes all non-motorized transport as it is called "human-powered mobility". Such as pedestrian, bicycles as an alternative to using cars. Consequently, knowing how high or low does public accept elements of different sustainable development is very important.

\subsection{Soft mobility "Slow Traffic":}

Soft mobility includes all types of Non-Motorized Transportation methods (NMT) that depends only on human energy (Human Powered Mobility). Slow traffic guidelines drawn by the Federal Roads Office (FEDRO) in 2002, is a framework to define general conditions for improving mobility system at urban and regional level. Swiss is the most significant example of public policy involved in integrating slow traffic into mobility system globally. Soft mobility which includes: pedestrian, bicycle and other non-motorized methods are "zero impact" mobility as an alternative to using cars. According to what was mentioned, slow traffic or soft mobility is a different way of expressing the same concept. Soft mobility can be defined as a special form of sustainable mobility that optimizes urban livability, through keeping individual right moving.

The global concept for sustainable mobility aims to increase urban livability, keeping individual right moving. Also, soft mobility can improve urban environment referring to:

- Air pollution \& noise Levels,

- Traffic congestion.

- Streets safety.

In general, soft mobility and its promotion in urban policies are linked to emissions problem generated by vehicular traffic. As is based on by increasing soft mobility this could reduce using private cars, with regard to short trips.

This should ensure highest levels of urban safety increasing occasions of public spaces regeneration. Despite this increase, network idea for soft mobility hasn't been carried out yet. Integrated facilities supply and services, being alternative to the car use, is still difficult to be accomplished.

\subsection{Mobility in New Urbanism}

New Urbanism, is a Nontraditional Design, and an urban design movement that started in the urban design field in the USA in 1980's, to enhance pedestrian movement in neighboring units. It had grown gradually in the direction of reforming the various aspects of urban planning and urban design. It influenced in urban areas according to standards of urban design to reform the built environment. Which had fostered life and placemaking quality? It had also retrieved the urban communities thought that includes various activities with short walking distance. New Urbanism provides walkable places, which give many options for people living an urban lifestyle in comfortable and enjoyable places. And drives the communities towards the utopian city.

New urbanism principles classification which is based on basis of three main levels:

1. Region: metropolis, city, \& town.

2. Neighborhood, district, and corridor.

3. Block, road, \& building.

According to a literature review pursued on CNU, new urbanism principles, at the neighborhood level are modified to be ten principles instead of nine (Carmona, 2010). Due to the scope of this research, only mobility in new urbanism principles related to neighborhood scale is addressed, and 
foster the community which gives choices for pedestrian movement with various activities for all users. These are, firstly Walkability, Secondly, Connectivity.

\subsubsection{Walkability:}

Accessibility is used often in human geography for evaluating facilities and functions spatial distribution. When any place is reached easily by pedestrians or by an appropriate mode of transport it becomes accessible; it denotes the ease with which any land-use activity can be reached from a location, using a particular transport system. Accessibility is considered also as the opportunity available to an individual or type of person to take part in a particular activity or set of activities.

\section{Typical accessibility measure is divided into two parts:}

A. Transportation elements, which represent travel difficulty or impendence. It is measured by travel distance, time, or costs (usually walking distance is measured by kilometer or mile while the distance covered by vehicles is measured by travel time) - (El Wakil, 2007).

B. Activity element represents opportunities available at a particular zone. It is indicated by the amount and the location of activities of different types. Everyone should have access to outdoor environments. Lack of accessibility could reduce individual and community activities participation and reduce people's ability to take advantage of some opportunities such as social, economic and healthy lifestyle.

Table 1: Accessibility's indicators, basic needs, and general goals

\begin{tabular}{|c|c|c|c|}
\hline \multicolumn{3}{|c|}{ Mobility and Sustainable Wellbeing } & Accessibility \\
\hline Indicator & $\begin{array}{c}\text { Toolbox for Measuring } \\
\text { Indicator }\end{array}$ & Basic Need & General Goal \\
\hline \multirow{3}{*}{$\begin{array}{c}\text { Pedestrian } \\
\text { Catchment } \\
\text { Area }\end{array}$} & $\begin{array}{l}\text { Converting street into } \\
\text { pedestrian thoroughfares }\end{array}$ & \multirow{3}{*}{$\begin{array}{l}\text { Maximum walking } \\
\text { distance before } \\
\text { turning back or } \\
\text { opting to drive a } \\
\text { bike or a car rather } \\
\text { than walk. }\end{array}$} & \multirow{7}{*}{$\begin{array}{l}\text { Improving public health by } \\
\text { encouraging daily physical } \\
\text { activity and reducing the } \\
\text { negative effects of vehicle } \\
\text { emissions. }\end{array}$} \\
\hline & $\begin{array}{lr}\text { Pedestrian } & \text { Catchment } \\
\text { Area For } & \text { Primary } \\
\text { Facilities } & \\
\end{array}$ & & \\
\hline & $\begin{array}{l}\text { Pedestrian Catchment } \\
\text { Area for Secondary } \\
\text { Facilities }\end{array}$ & & \\
\hline \multirow{4}{*}{ Connectivity } & $\begin{array}{l}\text { Turn public lots into } \\
\text { public square }\end{array}$ & \multirow{4}{*}{$\begin{array}{l}\text { Measure the ease of } \\
\text { access from one } \\
\text { point to another } \\
\text { within the } \\
\text { development }\end{array}$} & \\
\hline & $\begin{array}{l}\text { Comfortable climatic } \\
\text { conditions }\end{array}$ & & \\
\hline & Blocks Size \& façade & & \\
\hline & $\begin{array}{l}\text { Walk with } \\
\text { integrity and } \\
\text { overcrowding }\end{array}$ & & \\
\hline
\end{tabular}

\subsubsection{Walkability and Cyclability:}

Regular physical activity associated with enhanced health and reduces the risk of premature deaths. Physical activity reduces the risk of cardiovascular disease, stroke, diabetes type 2, colon cancer, osteoporosis, depression, and fall-related injuries. Walking is the most commonly promoted moderate-intensity physical activity, therefore walking and cycling are the most convenient and sustainable mode of transport for all local trips. The built environment has to provide a safe walkable and bicycle network in order to encourage people to walk or bike rather than use private cars. 
The key to pedestrian-friendly neighborhood is to tame than to exclude cars. Which means reducing traffic speed and reclaiming more street area for pedestrians without removing the entire cars. Streets can be made more attractive by widening pavements, providing cycle lanes and calming traffic (Rudlin and Falk, 2009).

Table 2: Walkability and Cyclability's indicators, basic needs and general goals

\begin{tabular}{|c|c|c|c|}
\hline \multicolumn{3}{|c|}{ Mobility and Sustainable Wellbeing } & $\begin{array}{c}\text { Walkability and } \\
\text { Cyclability }\end{array}$ \\
\hline Indicator & $\begin{array}{c}\text { Toolbox for Measuring } \\
\text { Indicator }\end{array}$ & Basic Need & General Goal \\
\hline \multirow{5}{*}{$\begin{array}{l}\text { Walkable } \\
\text { Network }\end{array}$} & $\begin{array}{ll}\text { Sidewalk } & \text { Network } \\
\text { Coverage } & \end{array}$ & \multirow{5}{*}{$\begin{array}{l}\text { Continues } \\
\text { walkable network } \\
\text { along both sides on } \\
\text { streets that links the } \\
\text { dwellings to } \\
\text { diverse uses within } \\
\text { the neighborhood. }\end{array}$} & \multirow{8}{*}{$\begin{array}{l}\text { Encourage pedestrian } \\
\text { activity without excluding } \\
\text { automobiles altogether. }\end{array}$} \\
\hline & $\begin{array}{l}\text { Good walking rhythm } \\
\text { with few interruptions }\end{array}$ & & \\
\hline & $\begin{array}{l}\text { Well-situated cafes and } \\
\text { outdoor restaurants }\end{array}$ & & \\
\hline & $\begin{array}{l}\text { Beautiful and effective } \\
\text { lighting }\end{array}$ & & \\
\hline & Good conditions & & \\
\hline \multirow[b]{2}{*}{$\begin{array}{l}\text { Cyclable } \\
\text { Network } \\
\text { and } \\
\text { Facilities }\end{array}$} & Bicycle Lane Km & \multirow{2}{*}{$\begin{array}{l}\text { Continue cyclable } \\
\text { network along the } \\
\text { streets that link the } \\
\text { dwellings to } \\
\text { diverse uses within } \\
\text { the neighborhood. }\end{array}$} & \\
\hline & Bicycle Facilities & & \\
\hline $\begin{array}{l}\text { Traffic } \\
\text { Calming }\end{array}$ & $\begin{array}{l}\text { Reduce traffic and } \\
\text { parking gradually }\end{array}$ & $\begin{array}{l}\text { Reducing vehicle } \\
\text { speeds within the } \\
\text { neighborhood. }\end{array}$ & \\
\hline
\end{tabular}

\section{Behavioral Dimensions: BD}

Behavior is defined and measured due to the importance to the success of any behavioral analysis. The target behavior characteristics must be sufficiently well defined to allow clear distinctions done between instances (cases where the target behavior has been emitted) and noninstances (cases where some other behavior has been emitted). Also, care must be exercised in behavioral selection dimension monitored to evaluate behavior changes over time.

Urban design through the classified documents relates to the relationship between man and the built environment can be represented in six common dimensions (UDD) (Carmona, 2010). Urban design documents (UDDs) are perceptual, functional, visual, temporal, behavioral and environmental dimension (Banerjee, 2001; Baran, 2003; Bartuska, 2007; Carmona, 2010), (Fig. 8). This research focuses on the criteria of behavioral dimension for the reason of being the most tangible dimension to the mobility of new urbanism principles. Table 3 illustrates the two main descriptive indicators of behavioral dimension (Desy,1990; Carr,1992; Gehl,2001; Berison,2008; Ilewelyn ,2010; Evans,2012). 
Table 3: Behavioral Dimension

\begin{tabular}{|c|c|}
\hline $\begin{array}{l}\text { Sub- } \\
\text { Issue }\end{array}$ & Indicators \\
\hline $\begin{array}{c}\text { Non- } \\
\text { Physical } \\
\text { Issues }\end{array}$ & $\begin{array}{l}\text { The interferes with the effect on human behavior are: } \\
\text { - Users physiological abilities that affect the behavioral response. } \\
\text { - An individual's personality that distinguishes him from others and made him } \\
\text { unique in interacting with the surrounding environment (personalization). } \\
\text { - Social context in which the individual resides determined by the rules which } \\
\text { routes, and framework of relations between individuals which imposes on all of } \\
\text { them. } \\
\text { - Cultural background as a set of social values and beliefs to which the individual } \\
\text { belongs to and that guide the behavior and from the experience. } \\
\text { - } \quad \text { Human needs such as social, Commercial, etc. } \\
\text { - } \quad \text { Public participation in all design process. } \\
\text { - } \quad \text { Freedom to act within public spaces. } \\
\text { - } \quad \text { Freedom in political practices. }\end{array}$ \\
\hline $\begin{array}{c}\text { Physical } \\
\text { Issues }\end{array}$ & $\begin{array}{l}\text { It interferes with the mutual effect on human behavior and the built } \\
\text { environment: } \\
\text { - The range of ownership of the vacuum due to property ownership between } \\
\text { public and semi-public. } \\
\text { - More limits of surrounding buildings and trees, the more powerful of the space } \\
\text { (enclosure). Defined edges and connected to the greater sense of containment } \\
\text { increase the positive interaction between man and environment. } \\
\text { - Movement system which affects the performance, and means of accessibility } \\
\text { and movement to the parking area. } \\
\text { - Treatment quality used in space raises the efficiency quality. }\end{array}$ \\
\hline
\end{tabular}

\section{Approach Apparatus}

As mentioned, the research suggests a tool to analyze the role of soft mobility in making cities livable and favorite. Thus, the paper formulates a matrix which called (indicators of soft mobility vs. behavioral dimension), Table 4 . The matrix tests behavioral milieu and soft mobility indicators based on the case study. It adopts a hypothesis concedes that the behavioral dimension is the most adjacent to the theory (Dunham, 2000). The matrix has two main axes: indicators of soft mobility and a general framework for behavioral dimensions. Table 4 shows indicators, which are concluded from the table. 1, and 2, list as five indicators within two main axes. Results achieved from the analysis of the matrix of relations between indicators and dimensions range is between high and low: The highest comes from high potentialities with low constrains; medium comes from low potentialities with low constraints, and the lowest comes from low potentialities with high constraints. The mutual impact of indicators versus dimensions showed as dots, no mutual impact showed as blanked cells. 
Table (4): A matrix which called (indicators of soft mobility vs. behavioral dimension) Source: Authors

\begin{tabular}{|c|c|c|c|c|c|c|c|c|c|c|c|c|c|c|}
\hline \multicolumn{2}{|c|}{ 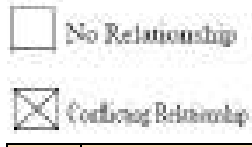 } & - Minual Relinicuatio & \multirow{2}{*}{ 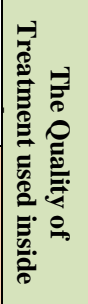 } & \multirow{2}{*}{ 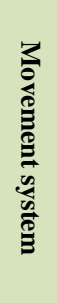 } & \multirow{2}{*}{ 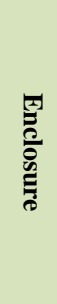 } & \multirow{2}{*}{ 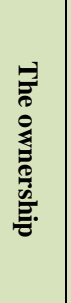 } & \multirow{2}{*}{ 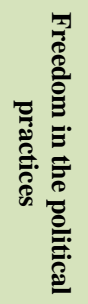 } & \multirow{2}{*}{ 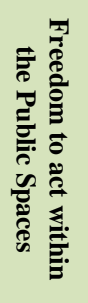 } & \multirow{2}{*}{ 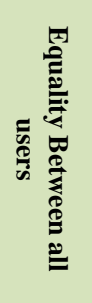 } & \multirow{2}{*}{ 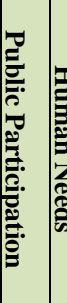 } & & \multirow{2}{*}{ 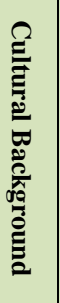 } & \multirow{2}{*}{ 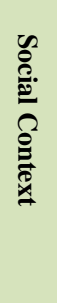 } & \multirow{2}{*}{ 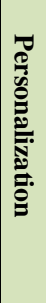 } \\
\hline & Indicator & $\begin{array}{l}\text { Toolbox for } \\
\text { Measuring } \\
\text { Indicator }\end{array}$ & & & & & & & & & & & & \\
\hline \multirow{7}{*}{ 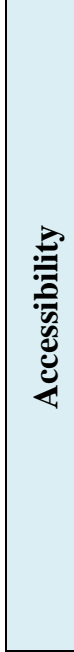 } & \multirow{3}{*}{ 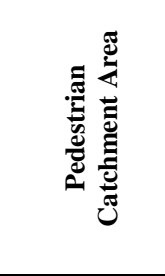 } & $\begin{array}{l}\text { Converting street into } \\
\text { pedestrian thoroughfares }\end{array}$ & & $\bullet$ & $\bullet$ & $\mathbf{X}$ & - & & & & $\bullet$ & $\bullet$ & & \\
\hline & & $\begin{array}{l}\text { Pedestrian Catchment Area } \\
\text { For Primary Facilities }\end{array}$ & & $\bullet$ & $\bullet$ & & & & & & $\bullet$ & $\bullet$ & - & \\
\hline & & $\begin{array}{l}\text { Pedestrian Catchment Area } \\
\text { for Secondary } \\
\text { Facilities }\end{array}$ & & - & - & & & & & & - & $\bullet$ & - & \\
\hline & \multirow{4}{*}{ Connectivity } & $\begin{array}{c}\text { Turn public lots into a } \\
\text { public square }\end{array}$ & $\bullet$ & $\bullet$ & & & & & & - & $\bullet$ & $\bullet$ & & \\
\hline & & $\begin{array}{c}\text { Comfortable climatic } \\
\text { conditions }\end{array}$ & & & & & & - & & & $\bullet$ & $\bullet$ & • & \\
\hline & & Blocks Size \& façade & $\bullet$ & & $\bullet$ & $\mathbf{X}$ & & & & & $\bullet$ & & $\bullet$ & \\
\hline & & $\begin{array}{l}\text { Walk with dignity, } \\
\text { integrity and without } \\
\text { overcrowding }\end{array}$ & - & & $\bullet$ & & & - & & & - & $\bullet$ & & \\
\hline \multirow{8}{*}{ 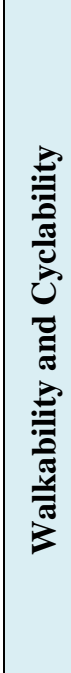 } & \multirow{5}{*}{ 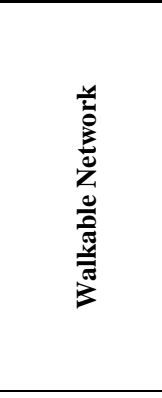 } & $\begin{array}{c}\text { Sidewalk Network } \\
\text { Coverage }\end{array}$ & & - & - & & & & & & $\bullet$ & $\bullet$ & - & \\
\hline & & $\begin{array}{l}\text { Good walking rhythm } \\
\text { with few interruptions }\end{array}$ & $\bullet$ & $\bullet$ & $\bullet$ & & & & & & $\bullet$ & • & - & - \\
\hline & & $\begin{array}{l}\text { Well-situated cafes } \\
\text { and outdoor } \\
\text { restaurants }\end{array}$ & • & & & & & - & & & - & $\bullet$ & • & - \\
\hline & & $\begin{array}{c}\text { Beautiful and effective } \\
\text { lighting }\end{array}$ & $\bullet$ & & & & - & & & & - & & - & $\bullet$ \\
\hline & & Good conditions & $\bullet$ & & & & & $\bullet$ & $\bullet$ & & $\bullet$ & & $\bullet$ & \\
\hline & \multirow{2}{*}{ 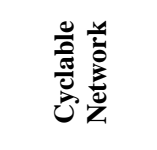 } & Bicycle Lane Km & & $\bullet$ & & & & & & & $\bullet$ & & & \\
\hline & & Bicycle Facilities & $\bullet$ & & $\bullet$ & & $\bullet$ & & & & $\bullet$ & & $\bullet$ & $\bullet$ \\
\hline & 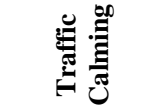 & $\begin{array}{l}\text { Reduce traffic and } \\
\text { parking gradually }\end{array}$ & & - & & & & & & & & $\bullet$ & - & \\
\hline
\end{tabular}

\subsection{Field Survey}

The surveying process aims and verifies indicators validity of soft mobility in Egypt. Table 5 shows surveying methods $\&$ techniques for the required task. Therefore, the field survey encompasses three main phases: appreciate the context, site analysis, and finally, getting concluded remarks Table 6. 
Table 5: Survey techniques and related methods

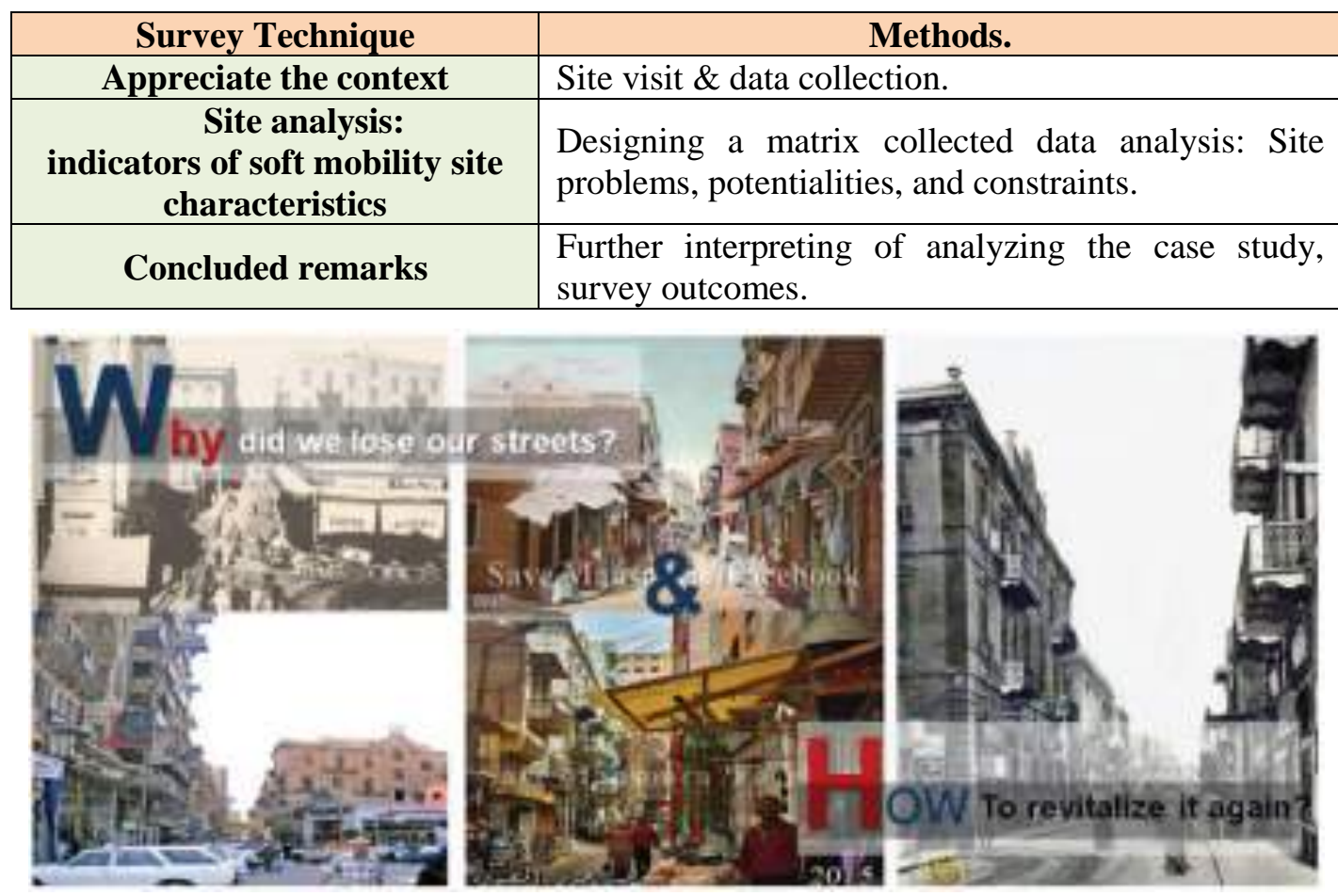

Fig. (2): A Photo showing Mansoura city streets in The past and Now

Source: Authors, http://english.ahram.org.eg .

\subsection{El-Seka El-Gededa "Commercial city center", Mansoura city: Appreciate the context}

Mansoura* as many other cities of Egypt had been modernized in the 18th century and its development has been evolving through a series of political designs. The case study area named revolution street (El-Seka El-gededa Street) which was named Ismail Street is the first street to be constructed within Mansoura old quarter and that was during Khedive Ismail (1863-1879) period according to in Mansoura old maps. Ismail's vision of modernization was to turn Egypt into a European country and Egyptian cities like Cairo, Alexandria, and Mansoura into European cities. He turned his back to the traditional quarter and started to build new districts and suburbs in European styles. 
*El-Mansoura: is an intermediate city in Egypt, Coordinates: $31^{\circ} 03^{\prime} \mathrm{N} 31^{\circ} 23{ }^{\prime} \mathrm{E}$. It is the capital of Dakahlia Governorate. Historically, Mansoura was the place where the crusaders were defeated and for this reason, its first name "The Rose Island" was converted to its recent name Mansoura "The Victorious". The City witnessed historical, political and economic development which affected the social life and communities in Mansoura. Now, the City is considered the third capital of Egyptian cities regarding its importance, population, economic activities, and political power.

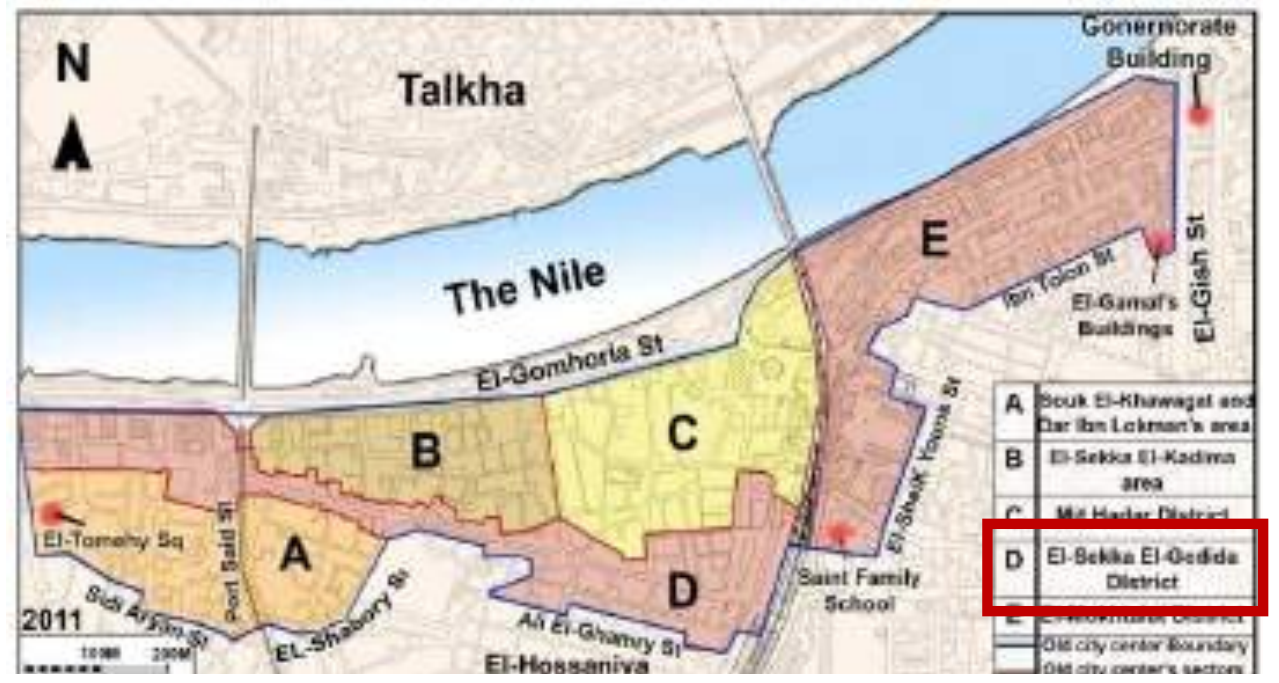

Fig. (3): El-Mansoura historical center highlighting main valuable culture regions map

Source: El-Gizawy, L., Shawky, M. Fouda, M., " The Effect of the Urban Heritage Sites Sustainable On The Development Of Intermediate Cities - Case Study: Mansoura City, Egypt" the 7th international engineering conference International Mansoura University, Egypt, (2010).

This area is nearby the Hussaniya area (southern El-Seka El-Gededa) the first planned area with urban fabric in Modern Mansoura and at the north located "Met-Hader" area which is the main commercial market with about $35 \%$ of (residential/commercial) activities (vegetables and fish market). The study area is considered to present about $50 \%$ of the Mansoura city commercial activities.

It is the oldest commercial area known in Dakahlia, which is divided into two parts as the first part; from Port-Said street where the Gold and Jewelry shops (AlSagha) (about 25\%), then the second part with cloth shops in the middle (around 55\%), and the shoe shops in the final part (20\%). in addition to a mix of uses of commercial activities with people and salesmen.

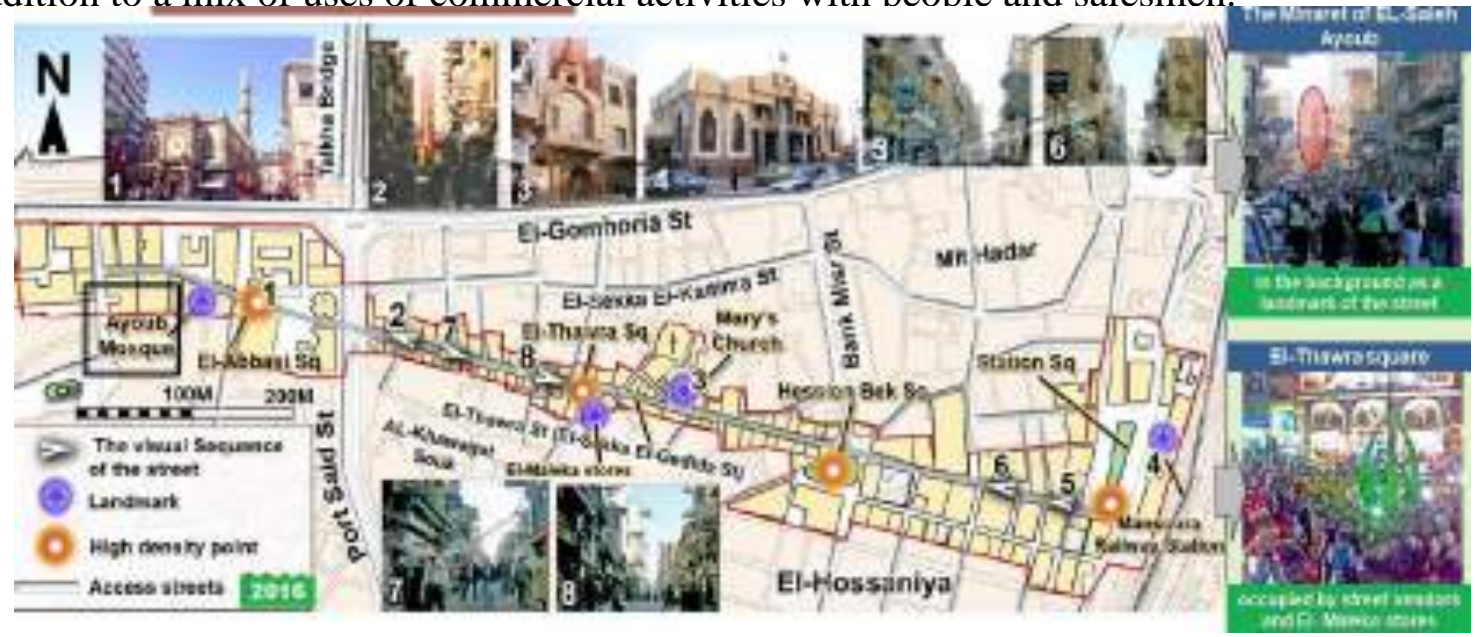

Fig. (4): The map shows high-density points, landmarks, and the visual Sequence Source: Authors 
From the property archives of the study area, most of the original owners were foreigners and now owned by Egyptians with mixed uses of commercial, residential and business activities (medical, offices and so on).

The area is faced by a set of influence factors; community priorities and needs (housing, infrastructure, and transport), the physical constraints (vacancies, potential, and obsolescence), regulatory constraints (authorities and legislation involved) and environmental constraints (air pollution and underground water). The ignorance of the existence of these constraints would discredit the practicality of any developmental actions and the sustainability.

El-Seka El-Gededa "Commercial city center" is the most predominance, functionally and visually, square in Mansoura city. Choosing El-Seka El-Gededa, as a case study, is due to its location as a focal point.

It contains various movement elements and behavioral aspects which could be analyzed from the perspective of indicators of soft mobility. In addition to its location, the cohabitation field of the researcher makes exploring the site more reliable. El-Seka El-Gededa locates within a distinctive place (Figure 4), as well as containing principles which contribute to configure responsive community. On the other hand, the master plan of El-Seka El-Gededa presents negative aspects from the perspective of the soft mobility that needs to be analyzed to overcome them.

\subsection{Testing Indicators vs. dimensions: Site analysis}

Analyzing the site aims to find out the current status of El-Seka El-Gededa. Table 6 represents the indicators of soft mobility versus the behavioral dimension. In addition to, this phase endeavor answers to the following question: to what extent does El-Seka El-Gededa conforms to the indicators of soft mobility?

Firstly, the pedestrian-friendly/walkability, and connectivity: The routs system achieves a high connectivity/permeability due to the street/block system which characterized by the medium size and street hierarchy. The site has several types of movement; these are the private cars, microbuses, and the pedestrian movement. The private car represents the main means of connectivity in this area. They benefit from the high connectivity realized by the street/block system. The street/block system gives all public spaces and places the quality of accessibility. Although this high connectivity is a positive factor for indicators of soft mobility, the car has the main dominance. This, in turn, affects the variety of activities and the exploitation of spaces by the other movement elements.

The shortage of parking places creates a basic problem that limits the capacity of urban spaces to achieve indicators of soft mobility; Cars can only park on the sides of the commercial axes. They even park sometimes on the sidewalks, these hazards in the pedestrian movement from the physical barrier to their movement.

Although public microbuses cover El-Seka El-Gededa, the dependency on this type is missing; quality of buses and bus stop locations are not suitable to the Mansoura inhabitants' way of life. In the initial layout of Mansoura, the routs appeared not separated from vehicle movement. Many factors enhance the efficiency of these paths and encourage people to use them; arcades to provide shadow for walkers. The site enjoys various types of landmarks. These enhance paths orientation, in addition to, exploring the place. The occupation of sidewalks by vendors and shops extensions represents another negative factor. 
Table (6): The matrix 'Pedestrian Friendly/Walkability, and Connectivity" Vs. Behavioral dimensions Source: Authors

\begin{tabular}{|c|c|c|c|c|c|c|c|c|c|c|c|c|c|c|c|c|}
\hline & $\stackrel{\bar{g}}{\underline{\underline{E}}}$ & $\begin{array}{c}\text { Toolbox for Measuring } \\
\text { Indicator }\end{array}$ & 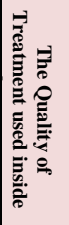 & 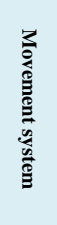 & 可 & 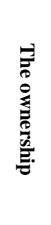 & 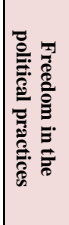 & 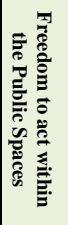 & 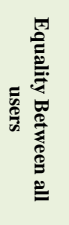 & 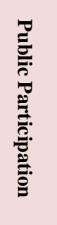 & 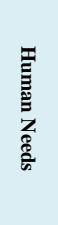 & 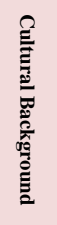 & 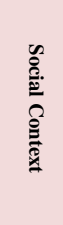 & 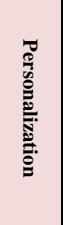 & 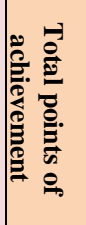 & de \\
\hline \multirow{14}{*}{ 音 } & \multirow{6}{*}{ 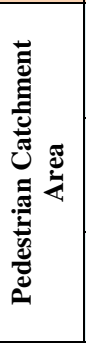 } & \multirow{2}{*}{$\begin{array}{l}\text { Converting street into pedestrian } \\
\text { thoroughfares (total } \\
\text { achievement } 5 \text { points) }\end{array}$} & & $\bullet$ & $\bullet$ & $\mathrm{X}$ & $\bullet$ & & & & • & - & & & \multirow[t]{2}{*}{$2 / 5$} & \multirow[t]{2}{*}{$40 \%$} \\
\hline & & & & 1 & 1 & & 0 & & & & 0 & 0 & & & & \\
\hline & & \multirow{2}{*}{$\begin{array}{l}\text { Pedestrian Catchment Area } \\
\text { For Primary Facilities (total } \\
\text { achievement } 5 \text { points) }\end{array}$} & & 0 & 0 & & & & & & 0 & 0 & 0 & & \multirow[b]{2}{*}{$2 / 5$} & \multirow[b]{2}{*}{$40 \%$} \\
\hline & & & & 0 & 1 & & & & & & 1 & 0 & 0 & & & \\
\hline & & \multirow{2}{*}{$\begin{array}{l}\text { Pedestrian Catchment Area For } \\
\text { Secondary Facilities (total } \\
\text { achievement } 5 \text { points) }\end{array}$} & & $\bullet$ & • & & & & & & • & - & • & & \multirow[t]{2}{*}{$2 / 5$} & \multirow{2}{*}{$40 \%$} \\
\hline & & & & 0 & 1 & & & & & & 1 & 0 & 0 & & & \\
\hline & \multirow{8}{*}{ 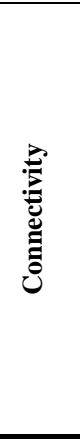 } & \multirow{2}{*}{$\begin{array}{c}\text { Turn public lots into public } \\
\text { square (total achievement } 5 \\
\text { points) }\end{array}$} & $\bullet$ & $\bullet$ & & & & & & $\bullet$ & $\bullet$ & $\bullet$ & & & \multirow{2}{*}{$1 / 5$} & \multirow{2}{*}{$20 \%$} \\
\hline & & & 0 & 1 & & & & & & 0 & 0 & 0 & & & & \\
\hline & & \multirow{2}{*}{$\begin{array}{l}\text { Comfortable climatic } \\
\text { conditions (total } \\
\text { achievement } 4 \text { points) }\end{array}$} & & & & & & $\bullet$ & & & $\bullet$ & $\bullet$ & $\bullet$ & & \multirow{2}{*}{$0 / 4$} & \multirow{2}{*}{$0 \%$} \\
\hline & & & & & & & & 0 & & & 0 & 0 & 0 & & & \\
\hline & & \multirow{2}{*}{$\begin{array}{c}\text { Blocks Size \& façade (total } \\
\text { achievement } 4 \text { points) }\end{array}$} & $\bullet$ & & $\bullet$ & $x$ & & & & & $\bullet$ & & $\bullet$ & & \multirow{2}{*}{$4 / 4$} & \multirow{2}{*}{$100 \%$} \\
\hline & & & 1 & & 1 & & & & & & 1 & & 1 & & & \\
\hline & & \multirow{2}{*}{$\begin{array}{l}\text { Walk with dignity, integrity } \\
\text { and without overcrowding } \\
\text { (total achievement } 5 \text { points) }\end{array}$} & $\bullet$ & & - & & & • & & & • & • & & & \multirow{2}{*}{$4 / 5$} & $80 \%$ \\
\hline & & & 0 & & 1 & & & 1 & & & 1 & 1 & & & & \\
\hline & & Sidewalk Network & & $\bullet$ & $\bullet$ & & & & & & $\bullet$ & $\bullet$ & $\bullet$ & & & \\
\hline & & $\begin{array}{c}\text { Coverage (total } \\
\text { achievement } 5 \text { points) }\end{array}$ & & 0 & 1 & & & & & & 1 & 0 & 0 & & 2/5 & $40 \%$ \\
\hline & & $\begin{array}{l}\text { Good walking rhythm with } \\
\text { few interruptions (total }\end{array}$ & • & - & - & & & & & & $\bullet$ & $\bullet$ & - & • & $4 / 7$ & $\mathbf{5 8 \%}$ \\
\hline & $\overline{\bar{z}}$ & achievement 7 points) & 0 & 1 & 1 & & & & & & 1 & 0 & 0 & 0 & & \\
\hline : & $\bar{z}$ & Well-situated cafes and & $\bullet$ & & & & & $\bullet$ & & & $\bullet$ & $\bullet$ & $\bullet$ & $\bullet$ & & \\
\hline$\frac{\pi}{0}$ & 常 & $\begin{array}{c}\text { outdoor restaurants (total } \\
\text { achievement } 6 \text { points) }\end{array}$ & 1 & & & & & 1 & & & 1 & 1 & 1 & 0 & $5 / 6$ & $83 \%$ \\
\hline 0 & $\bar{z}$ & Beautiful and effective & $\bullet$ & & & & $\bullet$ & & & & $\bullet$ & & $\bullet$ & $\bullet$ & & \\
\hline$\underset{\mathrm{E}}{\mathrm{J}}$ & & $\begin{array}{c}\text { lighting (total achievement } \\
\mathbf{5} \text { points) }\end{array}$ & 0 & & & & 0 & & & & 0 & & 0 & 0 & $0 / 5$ & $\mathbf{0 \%}$ \\
\hline : & & Good conditions (total & $\bullet$ & & & & & $\bullet$ & $\bullet$ & & $\bullet$ & & $\bullet$ & & & \\
\hline 馬 & & achievement 5 points) & 0 & & & & & 1 & 1 & & 0 & & 0 & & $2 / 5$ & $40 \%$ \\
\hline है & & Bicycle Lane Km (total & & $\bullet$ & & & & & & & $\bullet$ & & & & & \\
\hline & $\frac{2}{\frac{\pi}{0}}$ & achievement 2 points) & & 0 & & & & & & & 0 & & & & $0 / 2$ & $0 \%$ \\
\hline & 胥 & Bicycle Facilities(total & • & & $\bullet$ & & •. & & & & $\bullet$ & & $\bullet$ & •ㄴ. & & \\
\hline & & achievement 6 points) & 0 & & 0 & & 0 & & & & 0 & & 0 & 0 & $0 / 6$ & $\mathbf{0 \%}$ \\
\hline & 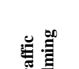 & Reduce traffic and parking & & $\bullet$ & & & & & & & $\bullet$ & $\bullet$ & $\bullet$ & & $1 / 4$ & $25 \%$ \\
\hline & Eच & achievement 4 points) & & 1 & & & & & & & 0 & 0 & 0 & & & \\
\hline & & No of points & $2 / 8$ & $4 / 8$ & $7 / 8$ & - & $0 / 3$ & $3 / 4$ & $1 / 1$ & $0 / 1$ & $7 / 15$ & $2 / 10$ & $2 / 11$ & $0 / 4$ & & \\
\hline & & Percentage $\%$ & 25 & 50 & 88 & - & $\mathbf{0}$ & 75 & 100 & $\mathbf{0}$ & 47 & 20 & 18 & $\mathbf{0}$ & & \\
\hline & & High Achievement & ium $A$ & hieve & nent & & & or Acl & ievem & & $x$ & & Confli & ting $\mathbf{R}$ & Relation & \\
\hline
\end{tabular}

Horizontally, the relationships between Blocks Size \& façade comparing with behavioral milieu score a high percentage "100\%". The same as the previous step, indicators such as 
Comfortable climatic conditions, Beautiful and effective lighting, Bicycle Lane Km, Bicycle Facilities have zero\% incompatibility with behavioral issues .

Therefore, these indicators should have the action priority in the re-designing process as they have the highest achievements in the study area.
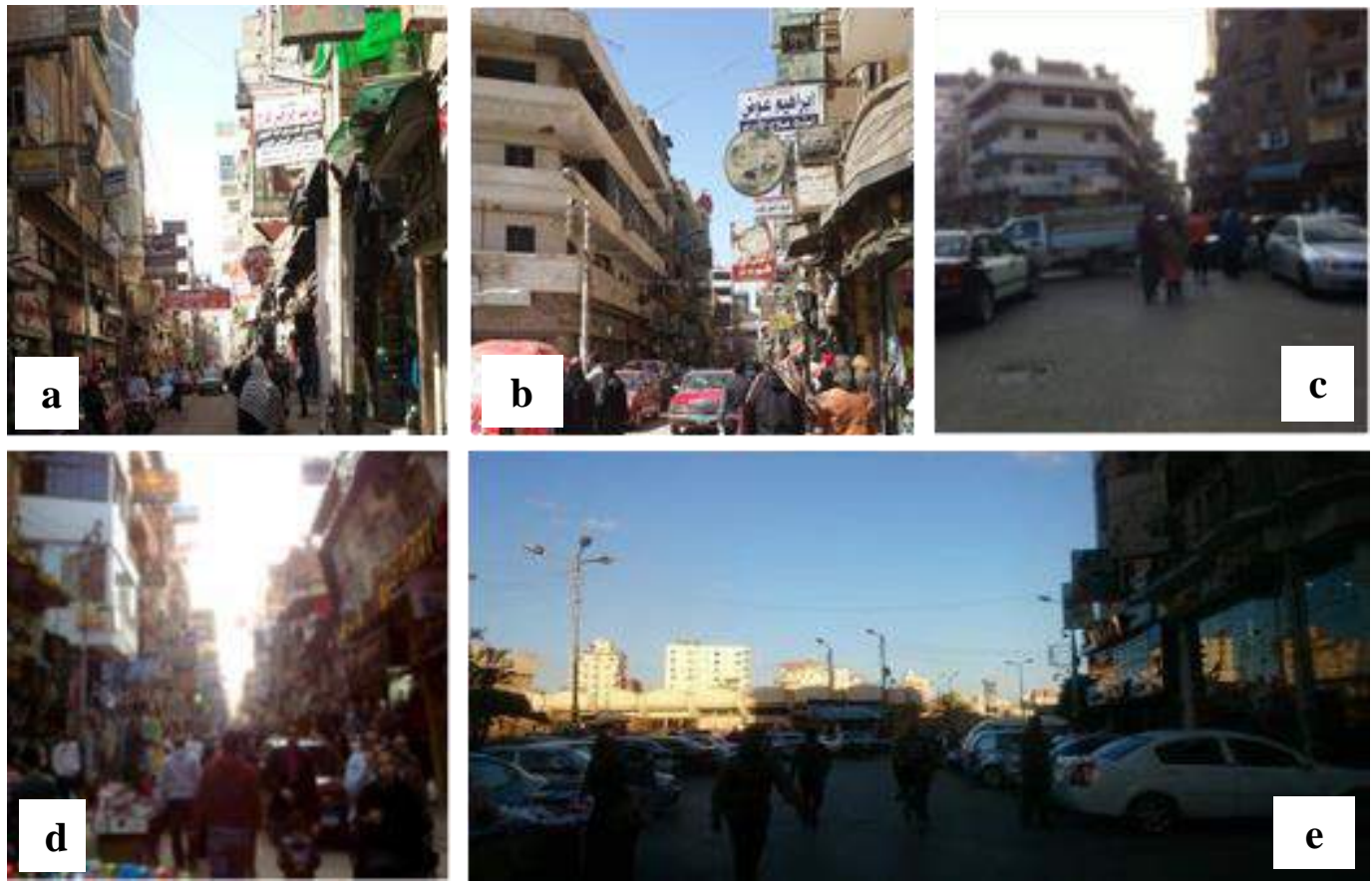

Fig. (5): The characteristics movement pattern in El-Seka El-Gededa:

(a) The high capacity of traffic in El-Seka El-Gededa Street; (b) the occupation of sidewalks by shops extension and roadside parking; (c) bad treatment of sidewalks pavement; (d) The occupation of sidewalks by vendors (e)the unsafe pedestrian movement

Source: Authors

\subsection{Concluding remarks: Survey outcomes}

From Table 4, the paper concludes some remarks.

Vertically, the issues equal between all users; Equality Between all users, Freedom to act with Public Spaces, and Enclosure took high grades percentage.

Consequently, it leads to the percentage of a weak equity among all users. On the other hand, the grades percentage that follow express of Human Needs, and Movement system range from medium to high .

Ultimately, the following three Indicators; Blocks Size \& façade, walk with dignity, integrity and without overcrowding, and Well-situated cafes and outdoor restaurants received the highest percentage. Furthermore, the last sub-issues of the behavioral dimensions received a weak percentage of the grade in comparison with indicators of soft mobility . 


\subsection{The Development Proposal:}

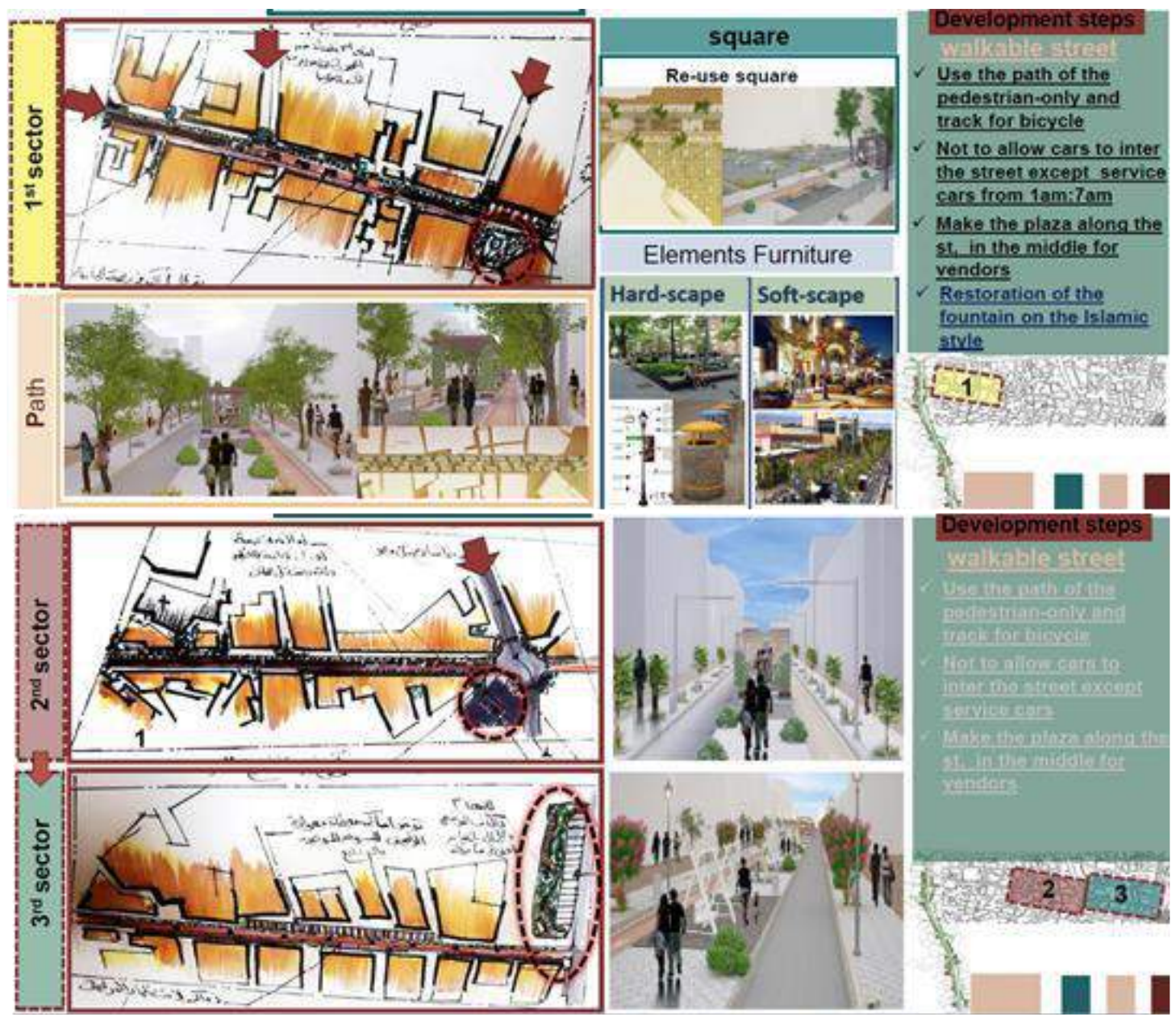

Fig. (6): The proposal of development by dividing in El-Seka El-Gededa Street into 3 parts

Source: Author

\section{Conclusions}

This research is done to find the relationship between indicators of soft mobility through one of the urban design dimensions under a certain hypothesis which might be true if taken into consideration the following:

- Public participation can play a great role in motivating the indicators and dimensions towards a real application

- Soft mobility indicators have to respect the cultural context of a certain context.

- Percentage of the mutual impact between indicators and dimensions numerically must be done by a digital model.

Current work followed the inductive analytically and an empirically approaches. focused on the quantitative analysis whereas a case study analysis depends on the results of the previous quantitative. This research was designed for this purpose, a matrix which addressed the indicators of soft mobility versus behavioral dimension and taking into account soft mobility to accommodate the change in human needs and rights. 
This research proposes further researches as a way to develop the proposed integrated approach, test a matrix. In addition to indicators of soft mobility that may play an important role in neighborhood units' constructive integration.

\section{References}

1. Ameen, R.F.M.; Mourshed, M.; Li, H. A critical review of environmental assessment tools for sustainable urban design. Environ. Impact Assess. Rev. 2015.

2. Ayman Mohamad Mostafa, (Quality of Life Indicators in Value Urban Areas: Kasr Elnile Street in Cairo). ASEAN Conference on Environment-Behavior Studies, Bangkok, Thailand, 16-18 July 2012.

3. Abeer Elshater, (New Urbanism Principles versus Urban Design Dimensions towards Behavior Performance Efficiency in Egyptian Neighborhood Unit). ASIA Pacific International Conference on Environment-Behavior Studies, Mercure Le Sphinx Cairo Hotel, Giza, Egypt, 31 October 2 November 2012

4. Abu Dhabi Urban Planning Council, "Abu Dhabi Urban Street Design Manual, Vision 2030", Abu Dhabi Urban Planning Council, Abu Dhabi, United Arab Emirates, 2011.

5. BRE Global, "BREEAM Communities - Integrating sustainable design into master planning", Bucknalls Lane, Watford - United Kingdom, 2013.

6. Boeing, Geoff; Church, Daniel; Hubbard, Haley; Mickens, Julie; Rudis, Lili. "LEED-ND and Livability Revisited". Berkeley Planning Journal, 2014.

7. E. Lora, A. Powell and others, "The Quality of Life in Latin American Cities, Markets and Perception", the Inter-American Development Bank, Washington, United States, 2010.

8. Florian Steinberg, Conservation and Rehabilitation of Urban Heritage in Developing Countries. Institute for Housing and Urban Development Studies, Rotterdam, The Netherlands, 1996.

9. Hassan, A.M.; Lee, H. Toward the sustainable development of urban areas: An overview of global trends in trials and policies. Land Use Policy 2015.

10. Jungwon Yoon, Jiyoung Park, "Comparative Analysis of Material Criteria in Neighborhood Sustainability Assessment Tools and Urban Design Guidelines: Cases of the UK, the US, Japan, and Korea", sustainability journal, ISSN 2071-1050,2015.

11. Sarah Abdel Moneim El Ariane, «Neighborhood Urban Quality of Life - Guidelines for Urban Planning and Development of New Assessment Tool>, FACULTY OF ENGINEERING, CAIRO UNIVERSITY, 2012.

12. Sharifi, Ayyoob; Murayama, Akito "A critical review of seven selected neighborhood sustainability assessment tools", Environmental Impact Assessment Review 38. 2013.

13. Sharifi, Ayyoob; Murayama, Akito "The potential of CASBEE for urban development for delivering sustainable communities: A case study from the "Koshigaya Lake Town" planning experience", International symposium on Urban planning, Taiwan,2012.

14. El-Gizawy, L., Shawky, M.,; Fouda, M., " The Effect of the Urban Heritage Sites Sustainable On The Development Of Intermediate Cities - Case Study: Mansoura City, Egypt" the 7th international engineering conference International Mansoura University, Egypt, 2010.

15. A.Rashed, D.Elkerdany, M.Shawky " Community Participatory for Sustaining Heritage Environments: Case Study Mansoura City", Mansoura University, Egypt, 2005. 